\title{
PERAN SPIRITUAL BERHUBUNGAN DENGAN PERILAKU SOSIAL DAN SEKSUAL REMAJA
}

\author{
Ardhian Indra Darmawan*, Shanti Wardhaningsih \\ Program Studi Magister Keperawatan, Fakultas Kedokteran dan Ilmu Kesehatan, Universitas Muhammadiyah \\ Yogyakarta, Jl. Lkr. Sel., Geblagan, Tamantirto, Kec. Bantul, Yogyakarta, Indonesia 55183 \\ *dhian.wae@gmail.com
}

\begin{abstract}
ABSTRAK
ABSTRAK

Setiap manusia yang ada di dunia memiliki keyakinan yang dianut. Spiritual adalah dasar dari kehidupan manusia dalam aktivitas kehidupan di dunia. Salah satu peristiwa yang terjadi dalam kehidupan adalah hubungan sosial antar manusia. Perkembangan manusia dimulai dari bayi, balita, anak-anak, remaja, dewasa sampai lanjut usia. Masa remaja adalah fase transisi yang berada diantara fase anak - anakmenuju fase dewasa. Setiap fase perkembangan manusia dipengaruhi oleh beberapa faktor, salah satunya adalah faktor lingkungankeluarga dan spiritual. Abad 21 memberikan potensi adanya pergeseran nilai emosional dan sosial remaja ke arah negatif, seperti pergaulan bebas yang dilakukan oleh remaja. Data diambil melalui PubMed, ProQuest, dan Google Cendekia menggunakan kata kunci: spiritual, sikap spiritual orang tua, perilaku sosial dan seksual remaja. Hasil dari delapan artikel yang diperoleh, diidentifikasi sebanyak empat tema, yaitu Spiritual dalam hubungan sosial, spiritual dalam perilaku dan kesehatan mental remaja, perilaku seksual berdasarkan budaya dan yang terkahir yaitu kontrol spiritual dalam perilaku dan pendidikan seksual. Hakekat dari nilai yang sosial yang terkandung dalam spiritual mampu memberikan dampak bagi kehidupan sosial remaja. Peran tingkat pengetahuan dan aplikasi nilai spiritual oleh orang tua dan lingkungan remaja tinggal mampu memberikan dampak bagi perilaku sosial remaja. Perilaku sosial remaja yang didalamnya terdapat perilaku untuk memenuhi kebutuhan biologisnya yaitu perilaku seksual. Remaja yang pengalaman hidupnya belum banyak, maka berisiko salah dalam mengambil keputusan untuk memenuhi kebutuhan dalam kehidupannya termasuk hubungan sosialnya. Meningkatnya pemahaman nilai spiritual akan mampu mengontrol perilaku yang dilakukan oleh remaja untuk memenuhi kebutuhan sosialnya.
\end{abstract}

Kata kunci: peran spiritual, perilaku sosial dan seksual, remaja

\section{SPIRITUAL ROLE DEALING WITH SOCIAL AND SEXUAL BEHAVIOR OF YOUTH}

\begin{abstract}
Every human being in the world have adopted beliefs. Spirituality is the foundation of human life in the world's life activity. One of the events that happen in life is the social relationships between people. Human development begins from infants, toddlers, children, teenagers, adults to elderly. Adolescence is a transitional phase that is between phases of a child - the child towards the adult phase. Each phase of human development is influenced by several factors, one of which is a spiritual family and environmental factors. The 21 st century provides the potential for a shift in adolescent emotional and social values in the negative direction, such as promiscuity conducted by adolescents. Data retrieved via PubMed, ProQuest, and Google Scholar using keywords: spiritual, spiritual attitudes of parents, social behavior and sexual. Results from the eight articles obtained, four themes were identified, namely spiritual in social relationships, spiritual behavior and mental health of adolescents, sexual behavior based on culture and finally spiritual control in sexual behavior and education. The nature of the social values contained in the spiritual can provide an impact on the social life of adolescents. The role of the level of knowledge and application of spiritual values by parents and the environment of adolescents living is able to have an impact on adolescent social behavior. Adolescent social behavior in which there is behavior to meet biological needs, namely sexual behavior. Teenagers, whose life experiences are not many, then risk making the wrong decision to meet the needs in their lives, including social relationships. Increased understanding of spiritual values will be able to control the behavior carried out by adolescents to meet their social needs.
\end{abstract}

Keywords: spiritual behavior, adolescents, adolescent sexual behavior 


\section{PENDAHULUAN}

Hasil survey sensus penduduk pada tahun 2015 jumlah penduduk usia 15 - 24 tahun sebesar 42.061,2 juta jiwa atau sebesar 16,5\% dari total jumlah penduduk Indonesia. Jumlah usia remaja di Indonesia diprediksi akan terus mengalami peningkatan sampai tahun 2030, dan setelah itu akan mengalami penurunan, dikarena adanya factor perubahan demografi dan fertilitas (Kusumaryani and Antarwati, 2017).

Masa remaja merupakan masa perubahan kondisi fisik, psikologis dan intelektual serta meningkatnya dorongan seksual terhadap lawan jenis, sebagai akibat dari perubahan hormonal (Kementerian Kesehatan RI, 2015; Kusumaryani and Antarwati, 2017).Perilaku sosial remaja dipengaruhi oleh factor pribadi dan lingkungan remaja. Faktor dari individu meliputi adanya usia akil baligh yang lebih cepat dibanding dengan teman yang lain( Parent et al cit, Berkley-patton, Bohn, Hawes, \& Bowe-thompson, 2015).

Akibat adanya perubahan fisik dan hormonal tersebut, remaja memilki perilaku sosial beresiko. Perilaku sosial beresiko tersebut memiliki dampak pada kondisi kesehatan, kondisi masa depan, konsep diri yang buruk dan lingkungan sosialnya (Kementerian Kesehatan RI, 2015; Kusumaryani and Antarwati, 2017). Kondisi usia remaja merupakan kondisi pada masa produktif maka hal ini perlu diperhatikan akan dampak negative sebagian besar akan dialami oleh wanita jika terjadi masalah dalam masa remaja tersebut (Heri and Cicih, 2017).

Faktor lingkungan pada zaman sekarang ini, menjadi resiko yang besar dalam proses tumbuh kembang remaja, mulai dari budaya liberal, teknologi yang canggih, acara televisi dan tontonan dalam bentuk video di dunia maya. Lingkungan yang ada tersebut bisa menjadi hal yang berbahaya bagi remaja jika remaja tidak mampu melakukan barrier terhadap itu semua. Remaja merupakan masa peralihan dari masa kanak - kanak menuju dewasa. Pada masa remaja merupakan suatu periode menuju sebuha kemandirian, kematangan dan otonomi, menurut mabey dan Sorensen (Geldard and Geldard, 2011).

Usia remaja menurut WHO adalah 10 - 19 tahun, sedangkan menurut peraturan menteri kesehatan Republik Indonesia nomer 25 tahun
2014 adalah 10 -18 tahun. Menurut WHO tahun 2014 jumlah populasi remaja di dunia sebesar 1,2 milyar atau $18 \%$ dari seluruh jumlah penduduk di dunia (Kementerian Kesehatan RI, 2015).

Jumlah remaja yang tergolong tinggi di Indonesia dan adanya pengaruh lingkungan remaja, maka potensi perilaku sosial remaja yang cenderung mengarah ke hal negative semakin tinggi. Kondisi ini diperkuat dengan hasil survey yang dilakukan oleh BPS, BKKBN dan Kementrian kesehatan pada tahun 2007 dan tahun 2012 terdapat dua kelompok umur yaitu usia 15 -19 tahun dan 20 -24 tahun (Kusumaryani and Antarwati, 2017).

Tahun 2007 perilaku seks pranikah pada laki laki kelompok usia 15-19 tahun sebesar 1,3\% dari jumlah populasi dan kelompok usia 20 24 tahun sebesar 1,4\% dari jumah populasi. Tahun 2012 perilaku seks pranikah pada laki laki kelompok usia 15 - 19 tahun sebasar 4,5\% dan kelompok usia 20 - 24 tahun 14,6\% dari jumlah populasi (Kusumaryani and Antarwati, 2017). Dalam kondisi diatas, maka orang tua dan keluarga memiliki peran dalam proses tumbuh dan berkembang remaja khusunya tentang perilaku seksual remaja (Simovska and Kane, 2015).

Perilaku seks pranikah merupakan bagian dari Perilaku seksual.Menurut Sarwono (2012), perilaku seksual adalah rangkaian tingkah laku yang berlandaskan hasrat seksual (Mandey, 2014). Tingkah laku yang muncul adalah rasa tertarik, keinginan untuk selalu bertemu, dan melakukan hubungan seksual (Mandey, 2014; Kusumaryani and Antarwati, 2017). Remaja merupakan salah satu aspek ketahanan nasional, jika aspek ini tidak dibina dengan baik akan berdampak pada system ketahanan nasional. Kondisi menunjukkan bahwa pentingnya remaja mendapatkan pendidikan kesehatan seks yang benar agar terhindar dari perilaku seks pra nikah dan seks bebas(Rinta, 2012).

Arus informasi yang mudah diakses oleh remaja dan keinginan untuk menikah usia muda yang menjadi factor utama remaja melakukan hubungan seksual diluar nikah. Kurangnya pemahaman orang tua tentang kesehatan seksual, jenis kelamin remaja dan pemahaman remaja tentang seksual yang kurang menjadi daya dasar remaja dalam 
memahami perilaku seksual yang sebenarnya (Yaunin and Lestari, 2016).

Perilaku remaja yang menyimpang tersebut perlu diberikan jalan keluar untuk mengatasi hal tersebut. Masalah perilaku merupakan cerminan dari dalam jiwa setiap individu remaja, maka jalan keluar yang diberikan adalah berhubungan dengan jiwa remaja yaitu berupa bimbingan akhlak. Akhlak dapat dibimbing dengan arahan dari nilai - nilai kebenaran yang hakiki yaitu agama (Al-Jaziri, 2000; Abdul Hafizh Suwaid, 2010; Subandi, 2016).

Bentuk dari bimbingan nilai agama adalah spiritualitas. Spiritualitas merupakan bentuk perilaku yang muncul dari konsep beragama yang diyakini oleh setiap individu atau manusia (Abdul Hafizh Suwaid, 2010; Subandi, 2016; Candra, Ayu Harini and Sumirta, 2017). Berdasarkan penjelasan tersebut, maka perlu dilakukan kajian lebih lanjut terkait hubungan spiritualitas dengan perilaku seksual pada remaja.

\section{METODE}

Artikel ilmiah yang sesuai dengan tema yang dipilih diambil dari date base yang telah disediakan oleh pubmed, proquest, Ebsco dan goggle cendekia. Kata kunci yang digunakan adalah spiritual, perilaku seksual, prilaku social, hubungan sosial remaja, peran orang tua dan jenis kelamin. Analisa ini ditujukan untuk memberi gambaran secara menyeluruh mengenai perilaku seksual remaja. Dalam melakukan literature review kriteria yang diambil adalah adanya pembahasan tentang spiritual, perilaku seksual remaja di Negara Indonesia. Artikel yang digunakan meliputi artikel berbahasa Inggris dimulai dari bulan Januari tahun 2013 sampai bulan November tahun 2017.

\section{HASIL}

Hasil identifikasi artikel yang sesuai dengan kriteria inclusi yang telah ditetapkan sebanyak 8 artikel. 8 artikel ini menjelaskan bahwa religiusitas / spiritual memiliki peran dalam perkembangan perilaku sosialdan seksual remaja. Nilai spiritual/religiusitas memiliki peran dalam mencegah kejadian perilaku antisosial. Spirtualiti juga mengatur tata cara dan pola menjalin hubungan sosial dan cara pandang atau persepsi membina hubungan sosial dalam pemenuhan kebuthan biologis secara benar. Terdapat empat kategoriyang dapat diambil kesimpulan dari proses literature review yaitu spiritual dalam hubungan interpersonalyaitu spiritual dalam hubungan sosial, spiritual dalam perilaku dan kesehtan mental remaja, perilaku seksual berdasarkan budaya dan kontrol spiritual dalam perilaku dan pendidikan seksual.

Terkait tentang kategori pertama yaitu spiritual dalam hubungan sosial remaja hal ini diambil dari tiga artikel penelitian yaitu pertama dengan judul "Religiosity and Antisocial Behavior: Evidence from Young African American Women in Public Housing Communities" yang dibuat olehChristopher P. Salas-Wright, Taqi Tirmazi, Margaret Lombe, Von E. Nebbitt (2015), artikel yang kedua dengan judul "Parent - Adolescent Relationships, Religiosity, and the social Adjustment of Indonesian Muslim Adolescent" yang dibuat oleh Doran C. French, Nancy Eisenberg and Julie Sallquist, Urip Purwono, ting Lu and Sharon Christ (2013). Artikel yang ketiga yaitu "Religiosity/Spirituality and Prosocial Behaviors Among Chinese Christian Adolescents: The Mediating Role of Values and Gratitude" yang disusun oleh Kin-Kit $\mathrm{Li}$, Wai-yin Chow (2014).

Tiga artikel diatas memberikan hasil dengan kesimpulan bahwa Spirtual mampu menjadi factor pecegahan pada remaja untuk berprilaku antisosial, agama memberikan dampak yang positif bagi hubungan orang tua dengan remaja/anak dan remaja dalam kehidupan bersosial, agama perlu diberikan ke remaja sebagai dasar dalam melakukan hubungan sosial. Kategori kedua yang didapatkan dari proses literasi adalah spiritual dalam perilaku dan kesehatan mental remaja. Kategori ini didapatkan dari artikel penelitian dengan judul "African American Adolescents Psychological Well-Being : The Impact of parents Religious Socialization on Adolescent" yang disusun oleh Sheretta T. Butler-Barnes, Pamlea P. Martin, Donte T. Boyd (2017) dan artikel yang kedua berjudul "Adolescent spiritual exemplars : exploring spirituality in the lives of diserve youth" yang disusun oleh Pamela Ebstyne king, Casey E. Clardy and Jenel Sanchez Ramos (2014).

Hasil dari dua artikel diatas menjelaskan bahwa Religious orang tua memberikan kesan nilai positif bagi remaja dalam memahami agama, perbuatan dan kesejahteraan psikologis. Dimensi spiritualitas dalam artikel 
diatas terbagi menjadi tiga hal yaitu: transendensi, kesetiaan dan tingkah laku. Tiga makna dimensi Spiritualitas ini menjadikan remaja memiliki rasa moral, mental dan komunitas yang tinggi.

Kategori yang ketiga yang berhasil didapatkan dari hasil literasi ini adalah perilaku seksual berdasarkan budaya, kesimpulan ini diambil dari hasil artikel penelitian yaitu "The Effect of School-Based Discrimination on Adolescents of Color Sexual Health Outcomes: A Social Determinants Approach" yang disusun oleh Brandon N. Respress, Ndidiamaka N. AmutahOnukagha dan Ijeoma opera (2017). Hasil yang didapatkan dari artikel ini menjelaskan bahwa ketidaksetaraan sosial budaya menyebabkan diskriminasi di sekolah yang berdampak pada perilaku seksual secara aktif.

Kategori yang terakhir atau yang keempat yaitu kontrol spiritual dalam perilaku dan pendidikan seksual. Kategori ini diambil dari artikel yang berjudul "Why Virginity Pledges Succeed or Fail: The Moderating Effect of Religious Commitment Versus Religious Participation"yang disusun oleh Antoinette M. Landor • Leslie Gordon Simons (2014). Judul artikel yang kedua untuk kategori yang keempat adalah "A Level Discomfort! Exploring the Relationship Between Maternal Sexual Health Knowledge, Religiosity and Comfort Discussing Sexual Health Issues with Adolescent" yang disusun oleh Fiona Farringdon, Courtney Holgate, Fleur Mclntyre, Max Bulsara (2013).

Kesimpulan hasil dari artikel tersebut adalah Religius atau spiritual memiliki dampak yang positif bagi remaja untuk melakukan ikrar menjaga keperawanan. Religius yang tinggi pada remaja membuat mereka semakin siap dalam berikrar atau keseriusan dalam menjalin hubungan. Akan tetapi pada remaja yang melakukan ikrar tersebut tidak memiliki pemahaman religi yang baik, remaja tersebut berpotensi beresiko dalam perilaku seksual

Tingkat religiusitas yang tinggi pada seorang ibu cenderung merasa tidak nyaman, ketika berdiskusi dengan remaja terkait mansturbasi, kondom, aborsi, kekerasan seksual dan kontrasepsi. Hal ini terjadi karena setiap ibu yang ada dalam penelitian tersebut belum mendapatkan pemahaman yang benar tentang kesehatan seksual dan cara penyampainnya pesan kepada remaja.
Hubungan spiritual dengan kesehatan seksual. Dalam penelitian tersebut dijelaskan bahwa setiap remaja yang memiliki nilai spiritual yang baik berdampak pada pemahaman yang baik terhadap kesehatan kesehatan seksual yang benar. Kondisi ini dinyatakan dengan nilai hasil penelitian yaitu (Mann-Whitney U test $\mathrm{p}=0.105$ ) (Farringdon et al., 2014).

\section{PEMBAHASAN}

Agama memiliki peran penting dalam mengatur kehidupan ini, kehidupan setiap manusia dikendalikan oleh akhlak seseorang dalam diri manusia tersebut. Akhlak merupakan pengendali dalam jiwa seseorang, pernyataan sesuai dengan yang disabdakan oleh Nabi Muhammad SAW dalam kitab Ensiklopedia Muslim,Rasulullah SAW bersabda "saya diutus dimuka bumi ini hanya untuk menyempurnakan akhlak manusia". Makna dari perkataan Rasulullah SAW adalah bahwa segala bentuk perilaku yang muncul dari diri manusia adalah cerminan dari akhlak manusia (Al-Jaziri, 2000).

Nilai - nilai yang tergantung dalam agama dijadikan sebagai dasar dalam menghadapi masalah - masalah dalam kehidupan sosial. Nilai luhur agama dijadikan sebgai pedoman dalam mencari dasar solusi problematika dalam kehidupan. Problematika dalam kehidupan terkait hubungan antar individu manusia dan lingkungan alam. Agama merupakan dalam kehidupan manusia bermasyarakat (Marzali, 2016).

Analisa tentang agama diatas dihubungkan dengan kehidupan sosial. Spiritual yang merupakan bagian dari Agama mampu menjadikan para remaja untuk memiliki hubungan sosial yang baik, hal ini ditunjukkan dengan nilai $(\mathrm{OR}=0.04, \mathrm{CI}=0.01-0.39)$. nilai tersebut menggambarkan bahwa spiritual mampu mencegah perilaku anti social pada remaja (Salas-Wright et al., 2015) selaras dengan hasil penelitian diatas bahwa pendidikan karakter merupakan sebuah tindakan preventif bagi perkembangan hubungan sosial remaja. Pendidikan karakter yang dimaksud adalah mengkaji nilai - nilai yang terkandung dalam ajaran agama (Wahidin, 2013).

Masa remaja merupakan masa dalam menegaskan arti kehidupan. Masa remaja pemikirian kritis dan abstrak akan sebuah fenomena kehidupan mulai muncul, sehingga 
remaja akan mencari arti dari setiap fenomena yang ada (Subandi, 2016). Pemikiran yang seperti ini pada remaja perlu mendapatkan arahan dan bimbingan oleh lingkungan sekitar meliputi orang tua, keluarga, tokoh masyarakat dan masyarakat yang baik (Sumara, Humaedi and Santoso, 2017).

Spiritual didalam perilaku remaja memiliki peran yang siginifikan hal ini ditunjukan dengan hasil penelitian yang menunjukkan interaksi antara tingkat religion orang tua yang mensosialisasikan spiritual kepada anak menciptakan hubungan yang positif $(\mathrm{B}=0.30$, $\mathrm{P}<0,01)$. Nilai ini menerangkan bahwa semakin tinggi nilai spiritual remaja menciptakan perilaku remaja yang positif (Pamela, Donte and Martin, 2017).

Perilaku remaja merupakan refleksi yang didapat remaja berdasarkan panca indera mereka dan diwujudkan dalam bentuk perilaku yang belum di lakukan klarifikasi oleh remaja tersebut. Dalam kehidupan social remaja memilki resiko menjadi individu yang antisosial, karena mereka memiliki kehidupan sendiri atau kesenangan pribadi (Geldard and Geldard, 2011).

Agama memiliki peran dalam kehidupan remaja yang khususnya pada masalah kehidupan social. Spiritual memiliki peran dalam kehidupan remaja, hal ini sejalan dengan penelitian yang terdapat dalam table 1 . Hasil penelitian tersebut menyatakan bahwa religiusitas yang tinggi berhubungan dengan usia remaja dan penurunan perilaku perkelahian antar remaja (Salas-Wright et al., 2015). Dalam kehidupan berkeluarga ternyata spiritual mampu memberikan dampak positif hubungan interpersonal antara orang tua dengan anak. Kualitas hubungan interindividu mengalami peningkatan ketika nilai spiritual dijadikan patokan didalam proses kehidupan. Kondisi ini sesuai dengan penelitian yang menjelaskan bahwa tingkat spiritual keluarga khususnya orang tua mampu meningkatkan hubungan yang positif dan dinamis kepada anak (French et al., 2013).

Hubungan interpersonal pada remaja dipengaruhi oleh spiritual remaja dan spiritual keluarga. Penelitian yang dilakukan oleh French et al dan salah-Wright et al menjelaskan bahwa spiritual dapat mencegah kejadian abnormalitas perilaku remaja dalam kehidupan sosial. Spiritualitas merupakan salah satu bentuk terapi yang dapat diberikan kepada remaja yang mengalami abnormalitas perilaku social (Saifuddin, 2015).

Perilaku yang ditunjukkan oleh remaja merupakan cerminan dari kondisi mental remaja pada saat itu. Kondisi mental remaja ini dipengaruhi oleh lingkungan remaja tinggal. Menciptakan lingkungan yang kondusif sangat diperlukan oleh remaja untuk membentuk karakter dan mental remaja. Salah unsur yang mempengaruhi lingkungan untuk menjadi baik adalah norma agama. Agama mampu memberikan pengaruh yang signifikan terhadap kondisi kesehatan mental remaja (Wahyuni and Bariyyah, 2019).

Perilaku seksual remaja merupakan salah satu bentuk refleksi pertumbuhan perkembangan yang dialami oleh remaja. Perubahan hormone, perubahan fisik, biologisdan psikologis yang mendasari segala bentuk sikap dan perilaku remaja baik normal maupun abnormal (Geldard and Geldard, 2011; Kementerian Kesehatan RI, 2015). Perilaku seksual dipengaruhi oleh jenis kelamin, ras dan etnic budaya dari setiap remaja. Angka kejadian perilaku seksual yang menyimpang atau abnormal cenderung lebih banyak terjadi pada laki - laki dibanding dengan perempuan (Hauser, 2015; Respress, Amutah-Onukagha and Opara, 2018).

Nursal (2008) menjelaskan bahwa kondisi remaja laki - laki lebih banyak melakukan perilaku seksual yang menyimpang lebih banyak 4 kali lipat dibanding wanita. Data ini menunjang bahwa jenis kelamin mempengaruhi perilaku seksual pada remaja(Yaunin and Lestari, 2016). Faktor selain jenis kelamin adalah factor budaya merupakan salah satu dari beberapa faktor yang mempengaruhi remaja untuk melakukan hubungan seksual pranikah. Budaya yang dimaksud adalah sebuah budaya yang muncul akibat era digital dan bukan budaya asli dari Indonesia. Budaya ini memberikan dampak pada perilaku seksual remaja. Akses yang tidak terkontrol menciptakan kebebasan pada setiap orang untuk melakukan aktivitas di dunia maya.Menurut Damayanti dalam BKKBN (2007) menyatakan bentuk perilaku seksual remajaadalah berpegangan tangan, berciuman, melakukan oral seks dan berhubungan badan(Pratama and Setiyaningsih, 2015). 
Melihat beberapa factor diatas maka diperlukan sebuah solusi untuk mencegah semakin meluasnya dampak negative dari factor tersebut. Salah satu solusi yang muncul adalah nilai Spiritualitas. Spiritualitas mampu memberikan dampak yang positif bagi setiap individu. Spiritualitas mampu menjadi factor untuk menciptakan perilaku seksual yang positif. Perilaku seksual yang positif maksudnya adalah memahami dengan benar dan tepat dalam bersikap dan menentukan tindakan dalam memahami kesehatan seksual.

Sebuah penelitian dijelaskan bahwa efek yang baik dalam perilaku social adalah orang tua. Orang tua merupakan contoh yang tepat bagi anak atau remaja dalam berfikir, bersikap dan bertindak. Mengutip perkataan dari Imam Al Ghozali "bahwa setiap anak yang terlahir menjadi tanggung jawab setiap orang tua. Didalam anak tersebut terdapat sebuah jiwa / hati yang masih bersih. Dalam mengisi jiwa tersebut merupakan tanggung jawab orang tua. Dalam mengisi jiwa tersebu adalah dengan mendidiknya dengan nilai - nilai yang benar dan baik sesuai dengan perintah agama"(Abdul Hafizh Suwaid, 2010).

\section{SIMPULAN}

Nilai atau norma spiritual dalam agama mampu memberikan memberikan peran penting dalam pertumbuhan dan perkembangan remaja. Khusus dalam perkembangan diri remaja yaitu perilaku sosial dan perilaku seksual, dengan pendekatan agama yang tepat dapat lebih mengarahkan perilaku yang lebih adaptif bagi remaja. Lingkungan yang baik dan pemahaman agama serta tingkat pendidikan orang tua tentang kesehatan seksual perlu dipahami. Lingkungan yang baik dan tingkat pemahaman orang tua yang baik tentang nilai spiritual dan pendidikan seksual akan mempermudah dan membantu proses tumbuh kembang remaja menuju ke perkembangan yang baik.

\section{DAFTAR PUSTAKA}

Abdul Hafizh Suwaid, M. N. (2010) PROPHETIC Parenting. I. Edited by F. A. Aziz Qurusy. Yogyakarta: Pro-U Media.

\section{Al-Jaziri, A. B. (2000) ENSIKLOPEDI MUSLIM. 19th edn. Edited by F. Bahri. Beirut: Darul Falah.}

Candra, I. W., Ayu Harini, I. G. and Sumirta, I.
N. (2017) PSIKOLOGI JIWA. I. Yogyakarta: ANDI.

Farringdon, F. et al. (2014) 'A Level of Discomfort! Exploring the Relationship Between Maternal SexualHealth Knowledge , Religiosity and Comfort Discussing Sexual Health Issues with Adolescents', pp. 95-103. doi: 10.1007/s13178-013-0122-9.

French, D. C. et al. (2013) 'Parent-Adolescent relationships, religiosity, and the social adjustment of Indonesian muslim adolescents', Journal of Family Psychology, 27(3), pp. 421-430. doi: $10.1037 / \mathrm{a} 0032858$.

Geldard, K. and Geldard, D. (2011) Konseling Remaja 'Pendekatan Proaktif untuk Anak Muda'. III. Yogyakarta: Pustaka Belajar.

Hauser, J. R. (2015) 'The influence of religiosity on sexual behaviors: A qualitative study of young adults in the Midwest', 7(4), pp. 375-381.

Heri, L. and Cicih, M. I. S. (2017) 'Info Demografi 2017', LD-FE Universitas Indonesia, p. 19. Available at: https://www.bkkbn.go.id/pocontent/uploads/iNFO_DEMOGRAFI_2 017.pdf.

Kementerian Kesehatan RI (2015) 'Infodatin Reproduksi Remaja-Ed.Pdf', pp. 1-8. doi: 24427659.

Kusumaryani, M. and Antarwati, E. (2017) 'Brief Notes: Prioritaskan Kesehatan Reproduksi Remaja Untuk Menikmati Bonus Demografi', Lembaga Demografi FEB UI, pp. 1-6. Available at: http://ldfebui.org/wpcontent/uploads/2017/08/BN-062017.pdf.

Mandey, F. K. . (2014) 'Remaja merupakan kelompok potensial yang perlu mendapat perhatian serius . Proporsi penduduk berusia remaja Masyarakat ( FKM ) Universitas Hassanudin ( UNHAS ) pada tahun mahasiswa media pornografi mengenai akses hasil menunjukkan angka yang cukup besar $\therefore$, pp. $48-55$. 
Marzali, A. (2016) 'Agama dan Kebudayaan', (1958), pp. 57-75. doi: https://doi.org/10.24198/umbara.v1i1.96 04.

Moore, E. et al. (2015) 'Beliefs About Sex and Parent - Child - Church Sex Communication Among Church-Based African', Journal of Religion and Health. Springer US, pp. 1810-1825. doi: 10.1007/s10943-014-9950-z.

Pamela, S. T. B., Donte, P. M. and Martin, P. P. (2017) 'African American Adolescents , Psychological WellBeing: The Impact of Parents , Religious Socialization on Adolescents , Religiosity', Race and Social Problems. Springer US, 9(2), pp. 115-126. doi: 10.1007/s12552-017-9199-8.

Pratama, B. A. and Setiyaningsih, R. (2015) 'Efek Penggunaan Jejaring Sosial Terhadap Perilaku Seksual Pranikah Pada Remaja Di Smp Negeri 1 Sukoharjo', IJMS - Indonesian Journal On Medical Science, 2(2), pp. 1-9.

Respress, B. N., Amutah-Onukagha, N. N. and Opara, I. (2018) 'The Effects of SchoolBased Discrimination on Adolescents of Color Sexual Health Outcomes: A Social Determinants Approach', Social Work in Public Health. Routledge, 33(1), pp. 1-16. doi: 10.1080/19371918.2017.1378953.

Rinta, L. (2012) 'Peran Pendidikan Seksual Dalam Membentuk Perilaku Seksual Positif Pada Remaja Dan Implikasinya Terhadap Ketahanan Psikologi Remaja Di Kota Yogyakarta', p. 2012.

Saifuddin, A. (2015) 'Abnormalitas Perilaku pada Anak dan Remaja, Sudah Sebegitu Parahnya??', Proceeding Seminar Nasional 'Selamatkan Generasi Bangsa dengan Membentuk Karakter Berbasis Kearifan Lokal', pp. 216-232. Available at:

https://publikasiilmiah.ums.ac.id/bitstrea $\mathrm{m} /$ handle/11617/6502/24-Ahmad Saifuddin.pdf? sequence $=1 \&$ is Allowed $=$ y.

Salas-Wright, C. P. et al. (2015) 'Religiosity and antisocial behavior: Evidence from young african american women in public housing communities', Social Work Research, 39(2), pp. 82-93. doi: 10.1093/swr/svv010.

Simovska, V. and Kane, R. (2015) 'Sexuality education in different contexts : limitations and possibilities'. doi: 10.1108/HE-10-2014-0093.

Subandi, M. A. (2016) Psikologi Agama \& Kesehatan Mental. Yogyakarta: Pustaka Belajar.

Sumara, D., Humaedi, S. and Santoso, M. B. (2017) 'Kenakalan remaja dan penanganannya', 4.4 doi: https://doi.org/10.24198/jppm.v4i2.1439 3.

Wahidin, U. (2013) 'PENDIDIKAN KARAKTER BAGI REMAJA', Pendidikan Islam. doi: http://dx.doi.org/10.30868/ei.v2i03.29.

Wahyuni, E. N. and Bariyyah, K. (2019) 'Apakah spiritualitas berkontribusi terhadap kesehatan mental mahasiswa?', pp. 46-53. doi: https://doi.org/10.29210/120192334.

Yaunin, Y. and Lestari, Y. (2016) 'Artikel Penelitian Faktor-Faktor yang Berhubungan dengan Perilaku Seksual Remaja di Kota Padang', 5(2), pp. 448455. 
Jurnal Keperawatan Jiwa Volume 8 No 1 Hal 75 - 82, Februari 2020

FIKKes Universitas Muhammadiyah Semarang bekerjasama dengan PPNI Jawa Tengah 